\title{
Screening of Tomato Genotypes for Tolerance of Reduced Irrigation
}

\author{
Stanislava Grozeva, Daniela Ganeva and Galina Pevicharova
}

\begin{abstract}
Screening and selection of tomato accessions under conditions of $50 \%$ reduced irrigation was performed in the current study. The experiment was conducted at the Maritsa Vegetable Crops Research Institute with 10 determinate tomato accessions (five largefruited and five for processing) in two consecutive years (20162017). The productivity per plant, number and average fruit weight was recorded for two harvest periods - in the end of July and mid of August. The data indicated that reduced irrigation during growing season influenced more strong productivity per plant especially in the second harvest period. The decrease of the yield in two studied tomato groups was $59.3 \%$ and $54.2 \%$ respectively. In the first harvest period the reduction of yield was $46.3 \%$ and $27.2 \%$. Moreover the applied stress had the weaker negative effect on average fruit weight. In both studied tomato groups, the reduction of fruit weight below $30 \%$ was observed. The studied large-fruited tomato accessions showed low drought tolerance compared to the tomato accessions for processing. Three-way analysis of variance showed that watering regime influenced mainly the productivity per plant and fruit set while the average fruit was affected by genotype. Based on the present study tomato accessions BG 985 and BG Solaris suitable for breeding of drought stress were selected.
\end{abstract}

Keywords-Tomato, reduced irrigation, productivity, harvest period.

\section{INTRODUCTION}

Tomato (Solanum lycopersicum L.) is one of the most widely grown and consumed vegetables in the world. This fact is due to the high biological value of the fruits (high content of dry substance, vitamin $\mathrm{C}$, minerals, carotenoids, phenols etc.) and their use for both fresh consumption and processing. A creation of a large number of genetically close varieties, because of domestication and breeding work in tomato is one of the reasons for the loss of genetic diversity and it increases the sensitivity of varieties to biotic and abiotic stress [1]. Among the abiotic stresses drought and high temperature are the main factors limiting the crop development and productivity. Drought often accompanies heat especially in summer [2].

Tomato plants are very sensitive to water stress and show high correlation between duration of the drought and crop

Stanislava Yordanova Grozeva, Maritsa Vegetable Crops Research Institute, Plovdiv, Bulgaria,

Daniela Ganeva Ganeva, Maritsa Vegetable Crops Research Institute, Plovdiv, Bulgaria

Galina Todorova Pevicharova, Maritsa Vegetable Crops Research Institute, Plovdiv, Bulgaria yield [3]. The most sensitive stages after transplanting are the flowering and fruit development [4]. According to some authors the water stress at earlier stage of growth (20 day stage) is more inhibitory compared to the later stage (30 day stage) as a consequence which decreased growth and development caused by reduced photosynthesis [5], [6]. Reduced irrigation decrease fruit number because of flower abortion and fruit shedding but fruit size was a limiting factor to fruit production in tomato [7]. In many cases the market yield reduction can reach over 50\% [8]-[10].

In this regard breeding for drought-tolerant tomato varieties is an important and urgent task due to the increased frequency and duration of droughts caused by climatic change. There has been much research aiming to development of tolerant tomato varieties but the process is slow and difficult due to the complex and multigenic control of drought tolerance [11], [12]. The approaches to breeding drought-resistant included: 1. screening of available germplasm for drought tolerant/adapted varieties; 2 . hybridization with wide species distinguished by enhance drought tolerance; 3. genetic transformation [13], [14]. In order to achieve the develop of genotypes with enhanced tolerance to water stress it is essential to combine the knowledge required to agronomical, physiological, biochemical and genetic basis of water tolerance.

The aim of the present study is to establish tomato genotypes that despite stressful conditions - high temperatures and reduced irrigation retain a relatively constant yield and quality.

\section{MATERIALS AND METHODS}

The experimental work was carried out during the two summer seasons of 2016 and 2017 at the field of the Maritsa Vegetable Crops Research Institute in Plovdiv. The plant material consisted of 10 determinate tomato genotypes divided into two groups: large-fruited tomato for fresh consumption and industrial processing in juices and pulps - BG 252, BG 2040, BG Milyana, BG Marti, BG Solaris and for processing in peeled tomato - BG 985, BG 2086, BG K1, BG Kapri and $\mathrm{BG}$ Venera. The seeds of selected accessions were sown at the beginning of April in an unheated greenhouse. At the beginning of May five weeks' old tomato seedlings were transplanted into a field. Tomato plants were grown according to the technology for mid-season production of determinate tomatoes under two conditions of water availability - optimum 
(well-watered) and 50\% reduced irrigation (water-stressed). The experiment was conducted in a randomized complete block design with two replications by 10 plants (area $2.4 \mathrm{~m}^{2}$ ). A micro-flow drip irrigation method was used with dripping wings and distributors giving $2 \mathrm{~L} \mathrm{~h}^{-1}$, spaced $20 \mathrm{~cm}$ apart and placed along the row. Observations were recorded on five individual plants for each replication for productivity per plant $(\mathrm{g})$, average fruit weight $(\mathrm{g})$ and fruits per plant (number). The evaluation was performed in two periods - in the end of July (first harvest) and in the mid of August (second harvest).

Weather data were collected from June to August in 2016 and 2017. Air minimum and maximum temperature $\left({ }^{\circ} \mathrm{C}\right)$, air humidity (\%), rainfalls $\left(1 / \mathrm{m}^{2}\right)$ and soil moisture at 15 and 30 $\mathrm{cm}$ depth $(\mathrm{kPa})$ were recorded by weather station Caipos Wave (Caipos GmbH, Austria).

The results were given as means of ten independent (biological) replications. To compare differences among accessions grown in two watering regimes Duncan's multiple range tests were used. The decrease percentage $\left(\mathrm{D}_{\%}\right)$ was also calculated. Three-way analysis of variance was applied to show the effect of genotype, watering regime and period of harvesting on productivity, average fruit weight, fruit number and interaction between them (SPSS software).

\section{RESUlTS AND DISCUSSION}

Significant differences in temperature between two studied years were not observed (Table 1). In the period of 2016 and 2017 the daily mean temperature from June to August was $25^{\circ} \mathrm{C}$ ranged between $19.78{ }^{\circ} \mathrm{C}$ and $28.80^{\circ} \mathrm{C}$ as well as 17.10 ${ }^{\circ} \mathrm{C}$ and $32.02^{\circ} \mathrm{C}$ respectively. The highest value of maximum temperature was recorded in June and July with peaks over $37^{\circ} \mathrm{C}$ and $40^{\circ} \mathrm{C}$ in 2016 and 2017 respectively. The minimum temperature for the period June-August were from $10.07{ }^{\circ} \mathrm{C}$ to $21.34{ }^{\circ} \mathrm{C}$ in 2016. In 2017 the minimum temperature varied from $8.66^{\circ} \mathrm{C}$ to $22.88^{\circ} \mathrm{C}$.

TABLE I

TEMPERATURES AND RAINFALLS DURING THE EXPERIMENTAL PERIOD OF 2016 AND 2017

\begin{tabular}{|c|c|c|c|c|}
\hline \multicolumn{5}{|c|}{ 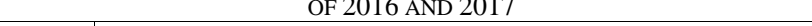 } \\
\hline \multirow{2}{*}{ Year } & & June & July & August \\
\hline & \multicolumn{4}{|c|}{ Temperature $\left({ }^{\circ} \mathrm{C}\right)$} \\
\hline \multirow[t]{3}{*}{2016} & Mimimum & $\begin{array}{c}18.39 \\
(14.84-21.16)\end{array}$ & $\begin{array}{c}17.93 \\
(14.29-21.34)\end{array}$ & $\begin{array}{c}17.01 \\
(10.07-21.21)\end{array}$ \\
\hline & Maximum & $\begin{array}{c}32.81 \\
(27.08-37.30)\end{array}$ & $\begin{array}{c}33.61 \\
(28.77-37.33)\end{array}$ & $\begin{array}{c}32.59 \\
(24.12-37.61)\end{array}$ \\
\hline & Daily mean & $\begin{array}{c}25.36 \\
(19.78-28.80)\end{array}$ & $\begin{array}{c}25.42 \\
(20.16-28.08)\end{array}$ & $\begin{array}{c}24.35 \\
(19.80-28.11)\end{array}$ \\
\hline \multirow[t]{4}{*}{2017} & Mimimum & $\begin{array}{c}17.18 \\
(13.07-22.88)\end{array}$ & $\begin{array}{c}17.64 \\
(12.76-21.24)\end{array}$ & $\begin{array}{c}16.92 \\
(8.66-21.60)\end{array}$ \\
\hline & Maximum & $\begin{array}{c}32.79 \\
(22.60-42.23)\end{array}$ & $\begin{array}{c}32.85 \\
(20.23-40.45)\end{array}$ & $\begin{array}{c}34.12 \\
(24.75-39.20)\end{array}$ \\
\hline & Daily mean & $\begin{array}{c}24.91 \\
(17.63-32.02)\end{array}$ & $\begin{array}{c}25.17 \\
(17.10-30.32) \\
\end{array}$ & $\begin{array}{c}25.28 \\
(20-28-29.75)\end{array}$ \\
\hline & \multicolumn{4}{|c|}{ Rainfalls $\left(1 / \mathrm{m}^{2}\right)$} \\
\hline 2016 & & 31.5 & 38.0 & 64.5 \\
\hline 2017 & & 19.5 & 52.5 & 4.5 \\
\hline
\end{tabular}

During the first experimental year the total rainfalls were $134 \mathrm{l} / \mathrm{m}^{2}$ more than the second one $\left(76.5 \mathrm{l} / \mathrm{m}^{2}\right)$ (Table 1). The period of 2017 was distinguished by lack of rainfalls in August except for $4.5 \mathrm{1} / \mathrm{m}^{2}$ while in the 2016 it was the month with the most rainfalls. The weather in June 2017 was also dry with only $19.5 \mathrm{l} / \mathrm{m}^{2}$ total rainfalls.

The response to water stress was mainly dependent on the genotype. The traits defining the yield (fruit number and average fruit weight) were influenced by the stress conditions and confirmed the sensitivity of the tomato varieties. The flowering passed normally when reduced irrigation was applied in June but stress conditions affected the fruit formation because of increases the flower shedding. Reduced watering combined with high temperatures in July had a significant impact on the number and quality of tomato fruits in the studied accessions (Table 2, 3).

TABLE II

IMPACT OF WATER DEFICIT ON FRUIT NUMBER, AVERAGE FRUIT WEIGHT AND PRODUCTIVITY PER PLANT IN LARGE-FRUITED TOMATO ACCESSIONS

\begin{tabular}{|c|c|c|c|c|c|c|c|}
\hline Genotype & & & st harves & & & ond har & \\
\hline & & $F N$ & $F W$ & Yield & $F N$ & $F W$ & Yield \\
\hline BG Milyana & $\mathrm{O}$ & $17.5^{\mathrm{a}}$ & $122.9^{\mathrm{bc}}$ & $2151^{a}$ & $11.2^{\mathrm{cd}}$ & $111.2^{\mathrm{b}}$ & $1241^{\mathrm{cd}}$ \\
\hline & $\mathrm{R}$ & $10.5^{\mathrm{c}}$ & $103.0^{\text {cde }}$ & $1082^{\mathrm{de}}$ & $7.0^{\mathrm{d}}$ & $92.2^{\mathrm{bc}}$ & $646^{\mathrm{e}}$ \\
\hline $\mathrm{D} \%$ & & 40.0 & 16.2 & 50.0 & 37.5 & 17.1 & 47.9 \\
\hline BG Marti & $\mathrm{O}$ & $13.0^{\mathrm{b}}$ & $132.7^{\mathrm{abc}}$ & $1727^{\mathrm{c}}$ & $16.5^{\mathrm{ab}}$ & $96.5^{\mathrm{bc}}$ & $1593^{\mathrm{bc}}$ \\
\hline & $\mathrm{R}$ & $10.0^{\mathrm{c}}$ & $98.3^{\mathrm{de}}$ & $983^{\mathrm{e}}$ & $10.0^{\mathrm{cd}}$ & $77.7^{\mathrm{d}}$ & $777^{\mathrm{e}}$ \\
\hline $\mathrm{D}_{\%}$ & & 23.1 & 25.9 & 43.1 & 39.4 & 19.5 & 51.2 \\
\hline BG Solaris & $\mathrm{O}$ & $10.0^{\mathrm{c}}$ & $147.4^{\mathrm{ab}}$ & $1474^{\text {cd }}$ & $13.0^{\mathrm{bc}}$ & $115.5^{\mathrm{a}}$ & $1502^{\mathrm{bc}}$ \\
\hline & $\mathrm{R}$ & $9.0^{\mathrm{c}}$ & $112.8 \mathrm{c}^{\mathrm{d}}$ & $1015^{\mathrm{de}}$ & $8.5^{\mathrm{d}}$ & $107.1^{\mathrm{b}}$ & $910^{\text {de }}$ \\
\hline $\mathrm{D} \%$ & & 10.0 & 23.5 & 31.1 & 34.6 & 7.3 & 39.4 \\
\hline BG 252 & $\mathrm{O}$ & $12.2^{\mathrm{b}}$ & $135.2^{\mathrm{abc}}$ & $1644^{\mathrm{c}}$ & $19.8^{\mathrm{a}}$ & $109.9^{\mathrm{b}}$ & $2180^{\mathrm{a}}$ \\
\hline & $\mathrm{R}$ & $8.5^{\mathrm{c}}$ & $85.8^{\mathrm{e}}$ & $730^{\mathrm{e}}$ & $9.5^{\mathrm{cd}}$ & $91.8^{\mathrm{bc}}$ & $872^{\mathrm{de}}$ \\
\hline $\mathrm{D}_{\%}$ & & 30.3 & 36.6 & 55.6 & 52.0 & 16.5 & 60.0 \\
\hline BG 2040 & $\mathrm{O}$ & $14.0^{\mathrm{b}}$ & $150.5^{\mathrm{a}}$ & $2107^{\mathrm{ab}}$ & $17.0^{\mathrm{ab}}$ & $109.0^{\mathrm{b}}$ & $1869^{\mathrm{ab}}$ \\
\hline & $\mathrm{R}$ & $9.0^{\mathrm{c}}$ & $119.7^{\text {cd }}$ & $1077^{\mathrm{dc}}$ & $7.0^{\mathrm{c}}$ & $93.9^{\mathrm{bc}}$ & $657^{\mathrm{e}}$ \\
\hline $\mathrm{D} \%$ & & 35.7 & 20.4 & 51.3 & 58.8 & 13.9 & 64.8 \\
\hline Average $\mathrm{D}$ & & 29.5 & 24.6 & 46.3 & 45.8 & 14.6 & 53.9 \\
\hline
\end{tabular}

The large-fruited determinate tomato accessions demonstrated low drought tolerance with significant reduction of fruit number and fruit weight (Table 2). Depending on the harvest period the reduction of yield was $46.3 \%$ and $53.9 \%$ respectively compared to the well-watered plants. Only one accession (BG Solaris) showed a decrease of productivity below $50 \%$. The studied determinate tomatoes for processing were more tolerant to applied stress especially in the first harvest period (Table 3). The reduction of yield was $27.2 \%$ and $54.9 \%$ respectively. Accession BG 985 distinguished by slight reducing of productivity per plant by $16.7 \%$ and $31.4 \%$ 
respectively. A decrease of productivity per plant in other accessions of this group varied from $16.6 \%$ to $48.7 \%$ for the first harvest period and from $30.0 \%$ to $66.8 \%$ for the second one. The same results with an overall yield loss in drought stress up to 55\% were observed by other authors [8], [9], [15]. The yield loss reached to $70-80 \%$ in the most susceptible genotypes [9].

TABLE III

IMPACT OF WATER DEFICIT ON FRUIT NUMBER, AVERAGE FRUIT WEIGHT AND PRODUCTIVITY PER PLANT IN TOMATO ACCESSIONS FOR PROCESSING

\begin{tabular}{|c|c|c|c|c|c|c|c|}
\hline \multirow[t]{2}{*}{ Genotype } & \multicolumn{4}{|c|}{ First harvest } & \multicolumn{3}{|c|}{ Second harvest } \\
\hline & & $F N$ & $F W$ & Yield & $F N$ & $F W$ & Yield \\
\hline \multirow[t]{2}{*}{ BG 985} & $\mathrm{O}$ & $10.5^{\mathrm{cd}}$ & $86.6^{\mathrm{a}}$ & $910^{\mathrm{cd}}$ & $15.8^{\mathrm{cd}}$ & $78.9^{\mathrm{a}}$ & $1249^{\mathrm{c}}$ \\
\hline & $\mathrm{R}$ & $9.5^{\mathrm{cd}}$ & $79.8^{\mathrm{ab}}$ & $758 \mathrm{~d}^{\mathrm{e}}$ & $13.5^{\mathrm{de}}$ & $63.4^{\mathrm{bc}}$ & $857^{\mathrm{d}}$ \\
\hline \multicolumn{2}{|l|}{$\mathrm{D}_{\%}$} & 9.5 & 7.8 & 16.7 & 14.6 & 19.6 & 31.4 \\
\hline \multirow[t]{2}{*}{ BG Kapri } & $\mathrm{O}$ & $14.3^{\mathrm{bc}}$ & $50.8^{\mathrm{cd}}$ & $728^{\mathrm{de}}$ & $15.0^{\mathrm{cd}}$ & $53.8^{\mathrm{de}}$ & $807^{\mathrm{d}}$ \\
\hline & $\mathrm{R}$ & $12.3^{\mathrm{bcd}}$ & $49.2^{\mathrm{d}}$ & $607^{\mathrm{e}}$ & $8.7^{\mathrm{e}}$ & $37.1^{\mathrm{f}}$ & $322^{\mathrm{e}}$ \\
\hline \multicolumn{2}{|l|}{$\mathrm{D}_{\%}$} & 14.0 & 3.1 & 16.6 & 42.0 & 31.0 & 60.1 \\
\hline \multirow[t]{2}{*}{ BG Venera } & $\mathrm{O}$ & $20.8^{\mathrm{a}}$ & $75.9^{\mathrm{b}}$ & $1582^{\mathrm{a}}$ & $31.5^{\mathrm{a}}$ & $77.0^{\mathrm{ab}}$ & $2425^{\mathrm{a}}$ \\
\hline & $\mathrm{R}$ & $24.2^{\mathrm{a}}$ & $50.9^{\mathrm{d}}$ & $1231^{\mathrm{b}}$ & $19.3^{\mathrm{bc}}$ & $41.6^{\mathrm{ef}}$ & $804^{\mathrm{d}}$ \\
\hline \multicolumn{2}{|l|}{$\mathrm{D}_{\%}$} & -16.3 & 32.9 & 22.2 & 38.7 & 46.0 & 66.8 \\
\hline \multirow[t]{2}{*}{ BG 2086} & $\mathrm{O}$ & $11.5^{\mathrm{bcd}}$ & $83.3^{\mathrm{ab}}$ & $958 b^{c d}$ & $22.0^{\mathrm{b}}$ & $80.7^{\mathrm{a}}$ & $1275^{\mathrm{b}}$ \\
\hline & $\mathrm{R}$ & $9.0^{\mathrm{d}}$ & $78.4^{\mathrm{ab}}$ & $706^{\mathrm{de}}$ & $12.7^{\mathrm{de}}$ & $67.5^{\mathrm{bc}}$ & $855^{\mathrm{d}}$ \\
\hline \multicolumn{2}{|l|}{$\mathrm{D}_{\%}$} & 21.7 & 5.9 & 26.3 & 42.3 & 16.4 & 51.8 \\
\hline \multirow[t]{2}{*}{ BG K1 } & $\mathrm{O}$ & $15.3^{\mathrm{b}}$ & $79.1^{\mathrm{ab}}$ & $1213^{b c}$ & $13.7^{\text {cde }}$ & $80.0^{\mathrm{a}}$ & $1094^{\mathrm{cd}}$ \\
\hline & $\mathrm{R}$ & $10.3^{\mathrm{cd}}$ & $60.1^{\mathrm{c}}$ & $622^{\mathrm{e}}$ & $13.7^{\text {cde }}$ & $56.2^{\text {cd }}$ & $768^{\mathrm{d}}$ \\
\hline \multicolumn{2}{|l|}{$\mathrm{D}_{\%}$} & 32.7 & 24.0 & 48.7 & 0.0 & 30.0 & 30.0 \\
\hline \multicolumn{2}{|c|}{ Average $\mathrm{D} \%$} & 9.8 & 15.3 & 27.2 & 30.7 & 28.2 & 54.9 \\
\hline
\end{tabular}

Drought stress had negative effects on the fruit formation. In the condition of reduced watering the number of fruits at the first harvest decreases with $29.5 \%$ in large-fruited tomatoes and $9.8 \%$ in the tomatoes for processing (Table 2, 3). The decrease recorded for the fruit number at the second harvest period was significantly higher with $45.8 \%$ and $30.7 \%$ respectively.

The accessions showed a lower decrease of the average fruit weight under conditions of 50\% reduced irrigation. Regarding the period of harvesting in the conditions of water stress the fruit weight reduced by $24.6 \%$ and $14.6 \%$ in the group of large-fruited tomato and with $15.3 \%$ and $28.2 \%$ in tomato for processing. Among the genotypes the lowest decrease of average fruit weight below $20 \%$ was established in two accessions for processing (BG 2086 and BG 985) and in two large-fruited accessions (BG Milyana and BG 2040).

The results were consistent with those established by other authors who found a decrease of number and weight of tomato fruits as a result of water deficit [7], [9]. Water stress decreases the number of ovules per floret and this is the main reason for the increased percentage of flower abortion in stressed plants [6]. Limiting of water at flowering stage not only reduces flower formation but also increases flower shedding [16].

The three-way analysis of variance indicated that the watering regime mainly influenced the productivity per plant $(63.94 \%)$ and fruit number (35.57\%) (Fig. 1a, c) while fruit weight was affected by genotype (68.34\%) (Fig. 1b).

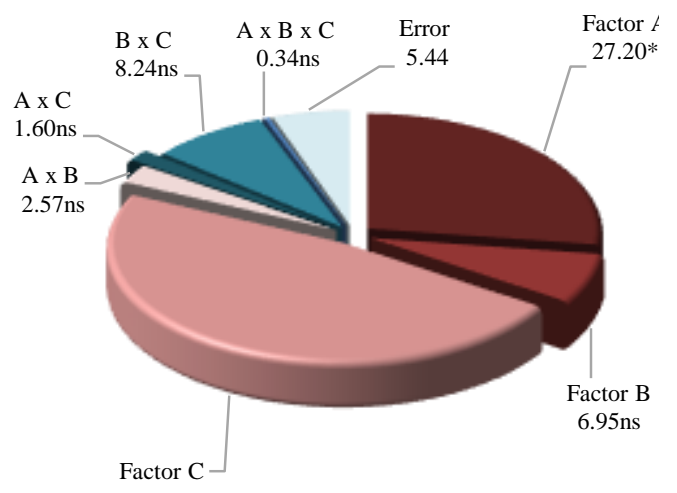

a.

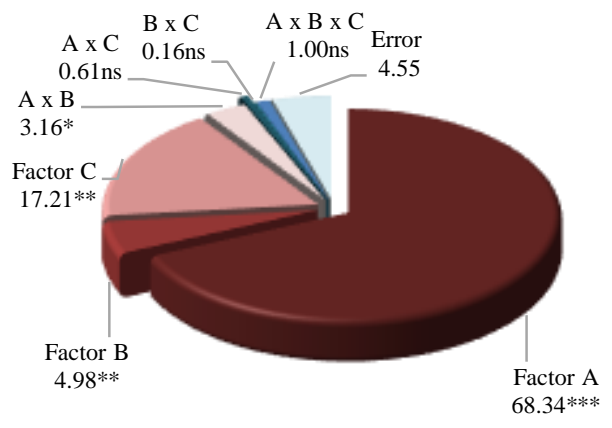

b.

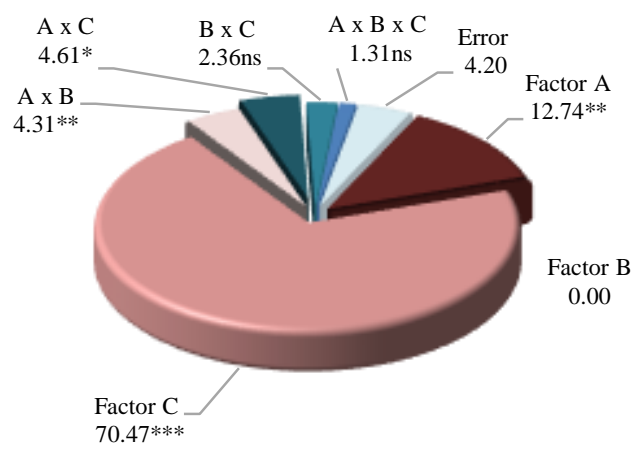

c.

Fig. 1. Three-way analysis of variance and power of influence of genotype (Factor A), period of harvesting (Factor B) and watering regime (Factor C); (a) fruit number, (b) fruit weight, (c) productivity per plant 


\section{CONCLUSION}

Water deficit combined with high temperature during the vegetative period (flowering phase) reduced the yield in tomato plants as a result of decrease of fruit set and average fruit weight. Large-fruited tomato accessions were more sensitive to applied drought stress compered to accessions for processing. The results showed that the watering regime influenced mainly the productivity per plant and fruit number while average fruit weight depended on genotype. Additionally, the number of fruits per plant was the most strongly affected by reduced irrigation and could be used as an indicator for the selection of tolerant genotypes. Among the genotypes tomato accessions BG 985 and BG Solaris were selected as tolerant to reduced irrigation and could be a base for the development of new varieties less sensitive to the drought stress.

\section{ACKNOWLEDGMENT}

This study is part of the TomGEM project that has received funding from the European Union's Horizon 2020 research and innovation programme under grant agreement No 679796.

\section{REFERENCES}

[1] P.J. Terzopoulos and P.J. Bebeli, "Phenotypic diversity in Greek tomato (Solanum lycopersicum L.) landraces," Sci. Hort., vol. 126, no. 2, pp. 138-144, September 2010. https://doi.org/10.1016/j.scienta.2010.06.022

[2] C. Jedmowski, A. Ashoub, O. Momtaz and W. Brüggemann, "Impact of drought, heat, and their combinationon chlorophyll fluorescence and yield of wild barley (Hordeum spontaneum)," J. Bot., vol. 6, pp. 1-9, 2015. https://doi.org/10.1155/2015/120868

[3] M. M. Nuruddin, C. A. Madramootoo and G. T. Dodds, "Effects of water stress at different growth stages on greenhouse tomato yield and quality," HortScience, vol. 38, no. 7, pp. 1389-1393, December 2003. https://doi.org/10.21273/HORTSCI.38.7.1389

[4] R. Vijitha and S. Mahendran, "Effect of moisture stress at different growth stages of tomato plant (Lycopersicon esculentum Mill.) on yield and quality of fruits," J Sci. Univ. Kelaniya, vol. 5, pp. 1-11, February 2012.

https://doi.org/10.4038/josuk.v5i0.4086

[5] H. Shamsul, S. A Hasan, Q. Fariduddin and A. Ahmad, "Growth of tomato (Lycopersicon esculentum) in response to salicylic acid under water stress," J. Plant Interact., vol. 3, no. 4, pp. 297-304, December 2008. https://doi.org/10.1080/17429140802320797

[6] I. C. Sibomana, J. N. Aguyoh and A. M. Opiyo, "Water stress affects growth and yield of container grown tomato (Lycopersicon esculentum Mill.) plants," GJBB, vol. 2, no. 4, pp. 461-466, 2013

[7] K. Birhanu and K. Tilahun, "Fruit yield and quality of drip-irrigated tomato under deficit irrigation," AJFAND, vol. 10, no. 2, pp. 21392151, February 2010. https://doi.org/10.4314/ajfand.v10i2.53356

[8] V. Cantore, O. Lechkar, E. Karabulut, M. H. Sellami, R. Albrizio, F. Boari, A.M. Stellacci and M. Todorovic, "Combined effect of deficit irrigation and strobilurin application on yield, fruit quality and water use efficiency of "cherry" tomato (Solanum lycopersicum L.)," Agric. Water Manage., vol. 167, pp. 53-61, March 2016. https://doi.org/10.1016/j.agwat.2015.12.024

[9] R. Sivakumar and S. Srividhya, "Impact of drought on flowering, yield and quality parameters in diverse genotypes of tomato (Solanum lycopersicum L.)," Adv. Hort. Sci., vol. 30, no. 1, pp. 3-11, 2016.

[10] M. Giuliani, F. Carucci, E. Nardella, M. Francavilla, L. Ricciardi, C. Lotti and G. Gatta, "Combined effects of deficit irrigation and strobilurin application on gas exchange, yield and water use efficiencyin tomato (Solanum lycopersicum L.)," Sci. Hort., vol. 233, pp. 149-158, March 2018. https://doi.org/10.1016/j.scienta.2018.01.052

[11] P. Langridge and M. P. Reynolds, "Genomic tools to assist breeding for drought tolerance," Curr. Op. Biotechnol., vol. 32, pp. 130-135, April 2015. https://doi.org/10.1016/j.copbio.2014.11.027

[12] I. Egea, I. Albaladejo, V. Meco, B. Morales, A. Sevilla, M. C. Bolarin and F. B. Flores, "The drought-tolerant Solanum pennellii regulates leaf water loss and induces genes involved in amino acid and ethylene/jasmonate metabolism under dehydration," Sci. Rep., vol. 8: 2791, February 2018. https://doi.org/10.1038/s41598-018-21187-2

[13] H. Hu and L. Xiong, "Genetic engineering and breeding of droughtresistant crops," Annu. Rev. Plant Biol., vol. 65, pp. 715-741, 2014. https://doi.org/10.1146/annurev-arplant-050213-040000

[14] S. S. Solankey, R. K. Singh, D. K. Baranwal and D. K. Singh, "Genetic expression of tomato for heat and drought stress tolerance: An overview," International Journal of Vegetable Science, vol. 21, no.5, pp. 496-515, October 2015. https://doi.org/10.1080/19315260.2014.902414

[15] L. Zotarelli, J.M. Scholberg, M. D. Dukes, R. Munoz-Carpena and J. Icerman, "Tomato yield, biomass accumulation, root distribution and irrigation water use efficiency on a sandy soil, as affected by nitrogen rate and irrigation scheduling," Agric. Water Manage., vol. 96, no. 1, pp. 23-34, January 2009. https://doi.org/10.1016/j.agwat.2008.06.007

[16] S. Mahendran and D. C. Bandara, "Effects of soil moisture stress at different growth stages on vitamin $\mathrm{C}$, capsaicin and $\beta$-carotene contents of chilli (Capsicum annuum L.) fruits and their impact on yield," Trop. Agric. Res., vol. 12, pp. 95-106, 2000. 